\title{
FISHING ACTIVITY, SIZE DISTRIBUTION, TAG RELEASED AND RECAPTURE OF TUNA TAGGING IN EASTERN INDONESIAN WATERS
}

\author{
Moh. Natsir, Anung Widodo and Budi Iskandar Prisantoso \\ Research Center for Fisheries Management and Conservation, Ancol-Jakarta \\ Received May 11-2011; Received in revised form December 13-2011; Accepted December 16-2011 \\ email: naseer.brpl@gmail.com
}

\begin{abstract}
Tagging of tropical tunas has a long history in Indonesian waters. Since 1987 tuna tagging has been conducted in Indonesian Waters. Tuna tagging in 2008 in eastern Indonesian waters was conducted in collaborative program with SPC to obtain new data about biological aspect and stock assessment of tuna. This tuna tagging was successfully conducted at 86 locations, with a total of 25,197 tuna tagged with conventional tags, at an average of around 900 fish per fishing day. The releases of conventional tags comprised of 19,576 skipjack (77.7\%), 5,267 yellowfin (20.9\%) and 354 bigeye (1.4\%). From the length frequency composition, the skipjack size range was wide, between 29 $-83 \mathrm{~cm}$, but mostly between 35 and $40 \mathrm{~cm}$ with $38.9 \mathrm{~cm}$ average. The yellowfin size range of $28-65$ $\mathrm{cm}$, with most fish between 37 and $41 \mathrm{~cm}$ of $40.1 \mathrm{~cm}$ average. The small numbers of bigeye tagged were mostly larger than $38 \mathrm{~cm}$, ranging from 29 to $58 \mathrm{~cm}$ with $41.3 \mathrm{~cm}$ average. During the tagging cruise, bait fish to support the fishing activity was relatively easily found in and around the survey area, either with direct catching using bouke ami net or purchasing from the lift net fisherman. By the end of $2010,4,594$ tags was recovered representing a relatively high recovery rate of $18.2 \%$ overall.
\end{abstract}

\section{KEYWORDS: Tuna, tagging, Eastern Indonesian Waters}

\section{INTRODUCTION}

Information on fish migration is very important not only for the study of the biological behavior, but also for that of population dynamics. Fish may have several different patterns of migration derived by their biological habits. In order to evaluate information on migration, tagging experiment is one of the powerful method, especially in quantitative information has been obtained for several species. Many techniques of tagging have been developed so that suitable tag has been matched to fish behavior and fishing method (Ishii, 1979). Tag recapture studies are also used to estimate mortality rates as well as the number of fish in a certain area (biomass). These methods are extensively reviewed by Jones (1977) \& Ricker (1975).

Tuna tagging in Indonesian waters especially in eastern Indonesian waters was already conducted since 1987 (Gafa et al., 1987). The success of the tuna tagging programs was indicated, amongst other things, by the high number of fishes being tagged. During the 1990s, a collaborative tagging program also conducted using MV Te Tautai and it also recorded as one of more successful tagging programs. The area covered by MV Te Tautai operations included Irian Jaya, Moluccas Sea, and North Sulawesi (Itano \& Opnai, 1991). Also a total of 1.180 fish had been tagged during 1990 tagging program in Bacan island, North Mollucas and Luwuk, central Celebes waters (Gafa \& Susanto 1991).
This paper described technical and operational aspects of the fifth cruise of the Pacific Tuna Tagging Project (PTTP) Phase 22008 carried out in eastern Indonesian Waters as a collaborative project between SPC (Secretariat of the Pacific Community)/OFP (Oceanic Fisheries Programme) and the Republic of Indonesia Research Centre for Capture Fisheries (RCCF). Ministry of Marine Affairs and Fisheries of the Republic Indonesia.

The global objectives of the Pacific Tuna Tagging Project (PTTP) were comprised of 5 objectives; to obtain data that will contribute to and reduce uncertainty in WCPO tuna stock assessments, to obtain information on movement and mixing of tuna in the equatorial WCPO, to obtain information on species-specific vertical habitat utilization by tunas in the tropical WCPO, to examine the impacts of FADs on tuna vertical behavior, and to obtain information on local exploitation rates and productivity of tuna in various parts of the WCPO, including eastern Indonesia.

\section{MATERIALS AND METHODS}

Tuna tagging in eastern Indonesian Waters was conducted during the cruise of the Pacific Tuna Tagging Project (PTTP) Phase 2 involving a 33 day period in Indonesian waters, from September 27th 2008 to October $30^{\text {th }}$. A chartered pole and line vessel from 
Solomon Islands (FV SOLTAI 105 with 199 GT size) was used during fishing and tagging operations.

The operation sequence during the tagging experiment involved baiting, fishing and tagging. Some genetic and biological sampling also conducted during the survey. Baiting for life bait was conducted using two ways, the first way was using a bouke ami net with underwater lights as attractor for the bait; baiting was conducted only when the weather and the location (depth, lack of current)was favourable. The second way to collect the bait was purchasing from local fishermen's lift net (bagan) catches.

The second activity of the tagging experiment was fishing using pole and line. Fishing activity started at daybreak (05.30 hrs) until late afternoon (18.00 hrs local time). Fishing was conducted arround FADs, free schools associated with log or floating materials i.e. bamboo, and even schools associated with whale sharks. Fishes from pole-and-line fishing was caught gently by the catcher and put on the special tagging cradle for length measurement and tag application. Fish were checked for good condition and generally released within 15 seconds of hooking.

Two types of conventional dart tags were using during the tagging experiment $-Z$ tags $(11 \mathrm{~cm}$ streamer length) for small fish of $31-37 \mathrm{~cm}$ fork length, and $P$ type tags $(13 \mathrm{~cm}$ streamer length) for bigger fish with more than $37 \mathrm{~cm}$ length. Figure 1 until Figure 3 show the tag types, illustration of tag placement under the second dorsal fin and example of the tags in live skipjack just prior to release (http://www.spc.int/ tagging/en/about-tagging).

Certain information regarding the tagging program such as tagging number and address to claim the tags reward were printed in waterproof printing on the tags.

Figure 1. Conventional Plastic Tag

\section{RESULTS AND DISCUSSION}

\section{FISHING ACTIVITIES}

The track of the cruise, based on school and noon positions, is depicted in Figure 4 with $3,691 \mathrm{~nm}$ total distance covered by the cruise. A wide area of the Pacific portion of the Indonesian EEZ was covered, similar coverage compared to 1991 tagging cruise,
(Figures 4,5). Tagging in 2008 was conducted at a total of 86 locations. A large array of FADs near Gebe Island produced only modest catches, using good bait obtained in Aljui Bay, so the vessel redirected activity to the north of Waigeo Island, where more than 4,000 fish were tagged in three days before heading towards Halmahera. Good quality bait was obtained at Morotai Island, but relatively small catches were made off the west coast of Halmahera. The vessel then headed for Kepaluan Islands to the south west, large amount of catches were made on FADs located to be in the western Seram Sea (over 4,000 fish in 3 days), enabled by good bait obtained on the north coast of Taliabu island.

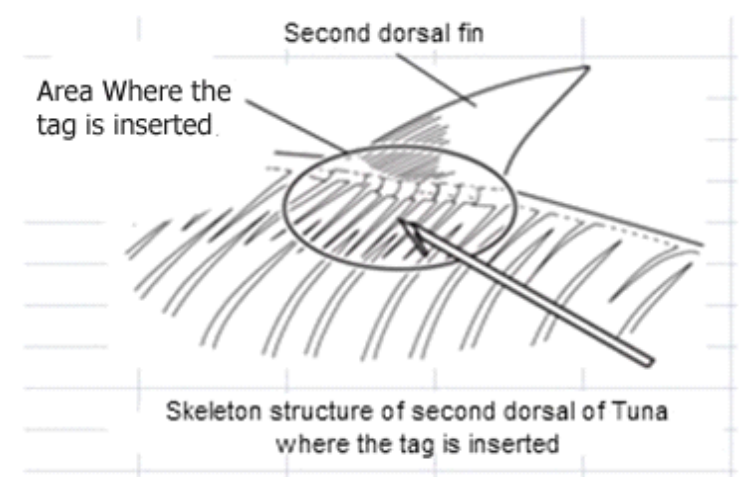

Figure 2. Illustration of tagging placement in a fish

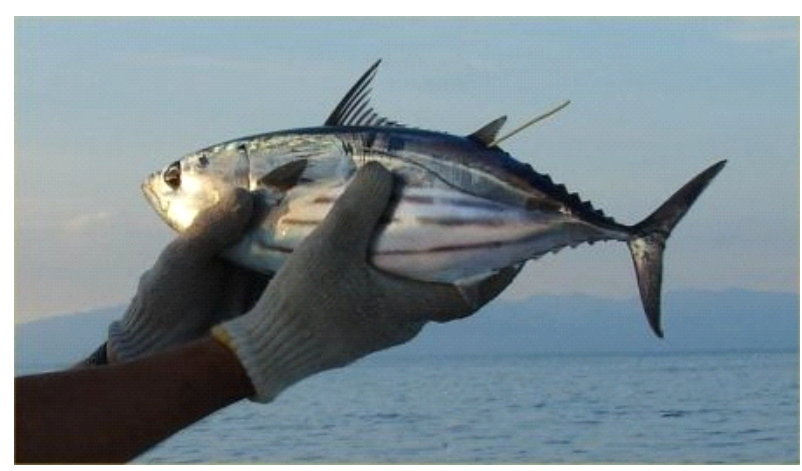

Figure 3. Skipjack tuna tagged with a conventional plastic tag.

Good fishing was found in Banda Sea, to the south of Ambon where over 200 fish were tagged and bait purchases from lift net/bagan in Saparua Island enabled the vessel to fish eastwards across the Banda Sea towards Papua. Good number catches were made in FADs south of Fakfak, before heading to the north coast of Seram Island. Bagan bait was then used to fish north with success towards Gebe Island. The final five days of the cruise were spent in the Nothern Papua 
waters, before clearing out of Indonesia in Jayapura on October $30^{\text {th }}$. A short trip to the 00/138E TAO buoy was made before Jayapura but with limited success due to the associated school being fished by a local purse-seiner from Jakarta prior to the arrival of the tagging vessel.

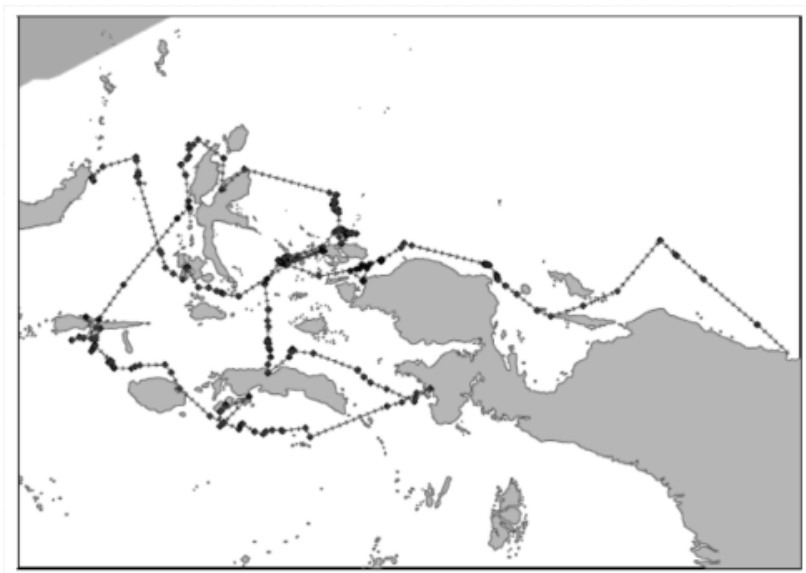

Figure 4. The track of 2008 tagging cruise

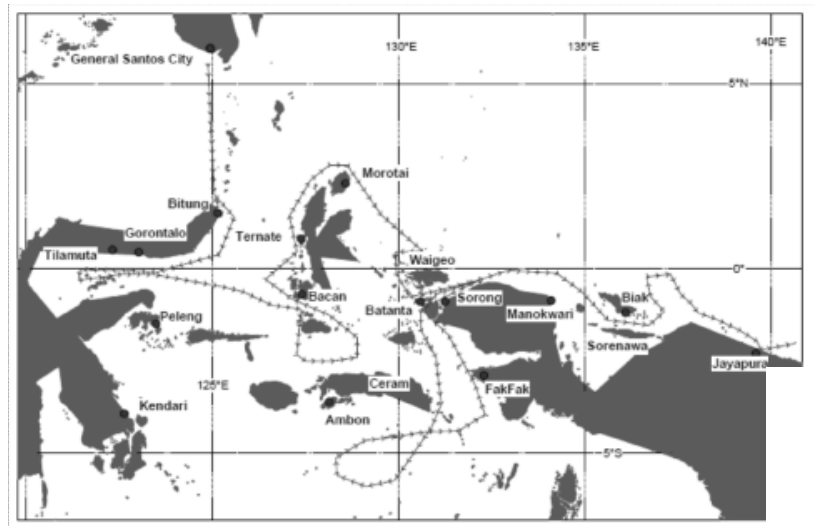

Figure 5. The track of 1991 tagging cruise (Itano Opnai. 1991)

\section{TAG RELEASES}

All of the 33 days of charter were spent Indonesian waters. Of these 33 days, 5.5 days we spent in port, and the remainder of the time was fishi time. The cruise time was relatively effectivu considered only small portion of the time with lack of bait or bad weather, and only two days total were spent steaming either without or with limited bait.
Most of fishing days were productive, with just two zero catch days. Total of are eighteen days of the cruise with more than 500 fish were tagged and released.

In total, 25,197 tuna were tagged with conventional tags, at an average of around 900 fish per fishing day. No archival or sonic tags were released. The releases of conventional tags comprised 19,576 skipjack $(77.7 \%), 5,267$ yellowfin $(20.9 \%)$ and 354 bigeye (1.4\%) (Figure 6). The "yellowfin plus bigeye" proportion of the catch, at $22.3 \%$, was lower than 1991 cruise, even though most fishing was on FAD-associated fish. Yellowfin comprised over $50 \%$ of the catch on just four fishing days, mostly in the area south of Kepaluan Islands. Bigeye were taken in small numbers throughout the cruise, but only more than 100 fish in a day on one occasion.

Over $80 \%$ of the 2008 releases were fished from anchored FADs which were not uniformly distributed throughout the Indonesian waters, but rather clumped in productive areas, invariably deeper than $1000 \mathrm{~m}$ and usually deeper than $2000 \mathrm{~m}$. Only $7.8 \%$ of releases were from free schools, and $9 \%$ from logs or drifting FADs. Whilst the majority of releases were from associated schools, only $25.4 \%$ of releases of conventional tags were the smaller $11 \mathrm{~cm} Z$ tags $(6,409)$, and $74.6 \%(18,788)$ the $13 \mathrm{~cm} P$ tags. The cruise releases are summarized by school in Appendix Table 1, while Figure 7 below shows the distribution of the releases in Indonesian waters by 0.5 degree square, by species.

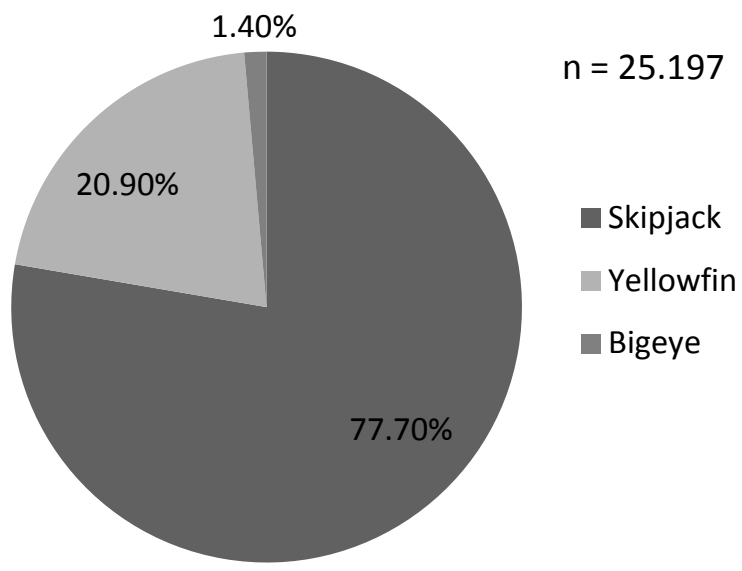

Figure 6. Tagged fish species composition 


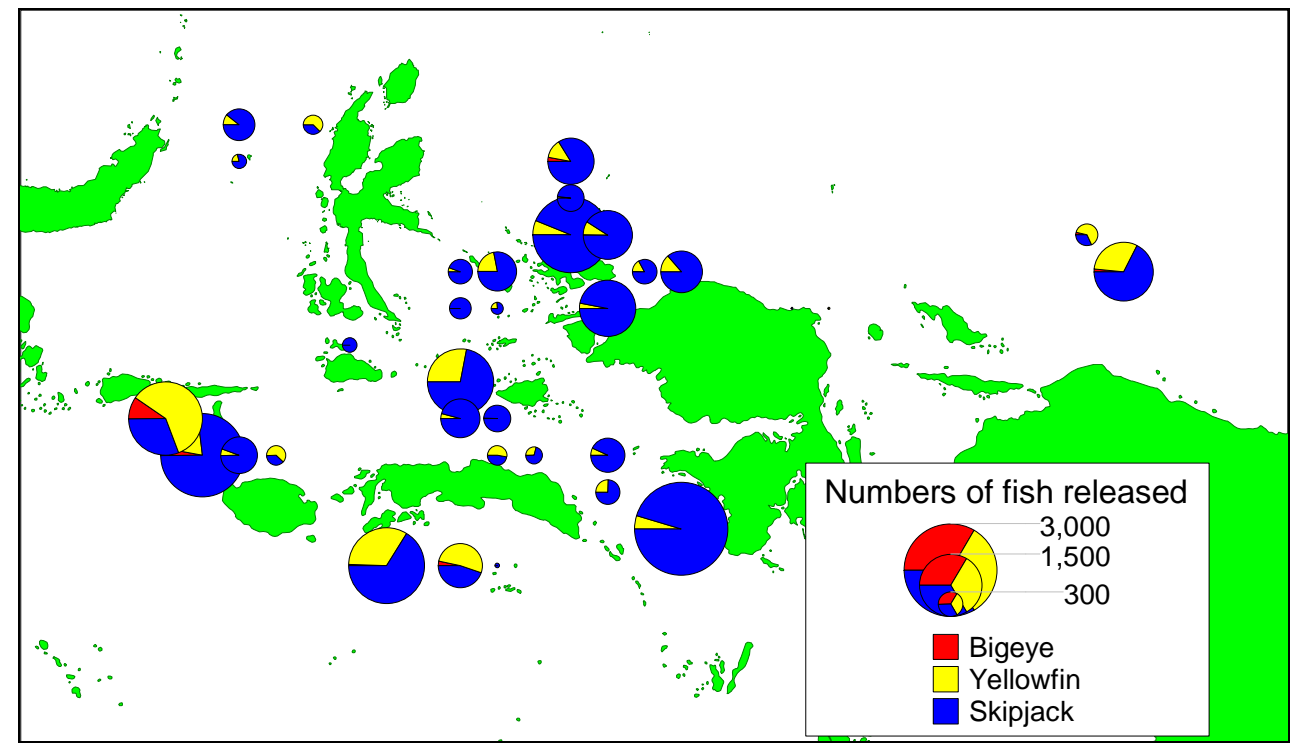

Figure 7. Distribution of releases in Pacific Indonesian waters of the Pacific by half degree square, by species, for PTTP Phase 2 Cruise 5 (28/09 to 30/10/2008)

\section{SIZE DISTRIBUTION OF TAGGED FISH}

Figures 8,9 and 10 show the size distribution of fish tagged during the cruise, while Table 1 shows the statistical summary of the length measurements. Skipjack size range was between $28-83 \mathrm{~cm}$ fork length, but from the length frequency graph, it can be seen that skipjack size was mostly between 35 and $40 \mathrm{~cm}$ (Figure 8).

Yellowfin size range was slightly smaller than skipjack, ranging from $28 \mathrm{~cm}$ to $65 \mathrm{~cm}$ length, but with most fish between 37 and $41 \mathrm{~cm}$ (Figure 9). The small numbers of bigeye tagged were mostly larger than $38 \mathrm{~cm}$, with size range were between 29 to 58 $\mathrm{cm}$ length (Figure 10).

Comparison with previous data from 1991 tagging shows that average size of the fish tagged in 2008 tended to be higher for yellowfin and bigeye, while for skipjack the average size was slightly smaller. From the standard deviation for three fish groups it is likely that the SD for 2008 tagging is much lower than 1991 tagging - this show that the size variation during 2008 tagging was lower than in 1991. Since most of the fishing during the 2008 tagging was done on FAD, with relatively homogenous size of the tagged fish that can be assumed as representative of size distribution fish associated with FAD.

Table 1. Summary of length frequency data collected from tuna tagged during the cruise

\begin{tabular}{clcc}
\hline Species & \multicolumn{1}{c}{ Statistic } & $\begin{array}{c}\mathbf{1 9 9 1} \\
\text { tagging }\end{array}$ & $\begin{array}{c}\mathbf{2 0 0 8} \\
\text { tagging }\end{array}$ \\
\hline \multirow{5}{*}{ YELLOWFIN } & Number of fish & 2,641 & 5,267 \\
& FL range $(\mathrm{cm})$ & $23-96$ & $28-65$ \\
& $\begin{array}{l}\text { Mean length } \\
\text { (cm) }\end{array}$ & 35.7 & 40.1 \\
& Std deviation & 8.2 & 3.9 \\
& Number of fish & 4,784 & 19,558 \\
SKIPJACK & FL range $(\mathrm{cm})$ & $23-75$ & $29-83$ \\
& Mean length & 39.2 & 38.9 \\
& (cm) & 8 & 3.8 \\
& Std deviation & 44 & 354 \\
& Number of fish & 44 & $29-58$ \\
BIGEYE & FL range $(\mathrm{cm})$ & $24-56$ & 29 \\
& Mean length & 35 & 41.3 \\
& (cm) & 5.9 & 3.7 \\
\hline
\end{tabular}




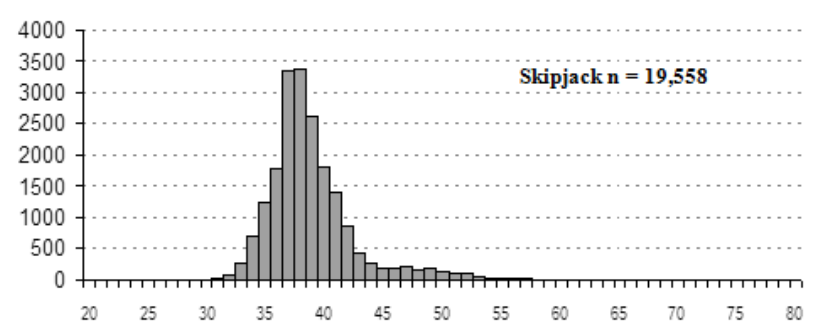

Figure 8. Size distribution of tagged skipjack

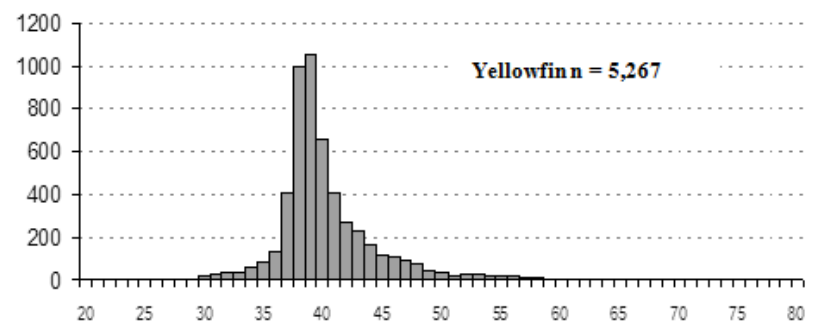

Figure 9. Size distribution of tagged yellowfin

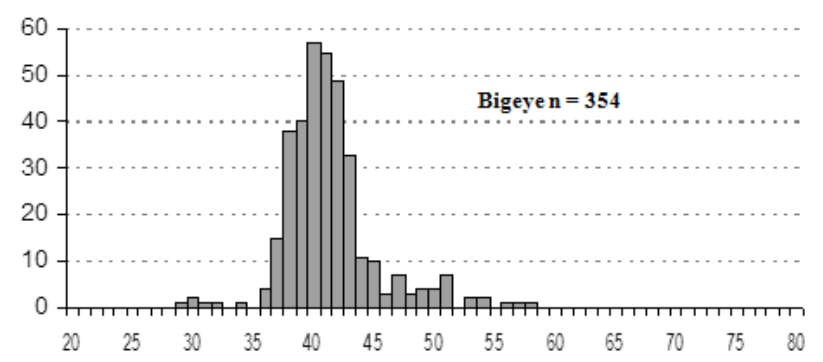

Figure 10. Size distribution of tagged bigeye

\section{BAIT FISHING}

The cruise was blessed with almost continuous good bait in plentiful supply, either from capture by the vessel itself using standard bouke ami gear or purchased from bagans, lift net vessels or platforms supplying bait to local pole-and-line vessels (funai and huhate). As noted, only two days during the cruise involved steaming with no bait, so bait was ultimately not a constraint.

Lights for bait fishing by the vessel were set on 15 nights in 12 locations. The average bait catch per night was 180 buckets, and was often supplemented with bait purchase from bagans. The tanks were filled on at least 10 occasions, enabling longer trips and translocations to new areas whilst fishing "en route".

Catches were dominated by anchovies Encrasicolina punctifer (ocean anchovy) was surprisingly common in the deeply shelving bays where baiting often occurred, whereas two other common anchovy species (E.devisi and E.heterolobus) were taken in the more extensive shallow bays. Sprats (Spratelloides spp.)were not taken in large numbers at any location, a species of sardine new to the vessel - presumed to be Sardinella longiceps, with very adherent scales and good survival, proved to be a mainstay in many areas. Larger small pelagic predators were often taken in numbers at many sites and often needed to be scooped out with larger mesh nets before loading of suitable-sized bait could commence.

Obtaining bait from lift nets or bagans proved to be very successful and was carried out on 5 occasions. After negotiations regarding bait availability and price, the vessel could move alongside the keeper net and the bait transferred with the help of bagan fishers, with usually vessel crew scooping the progressively crowded bait into larger buckets for quicker transfer. On most occasions, these larger buckets contained $4-5 \mathrm{kgs}$ of bait, or twice the usual bucket wet weight of bait used on the tagging vessel, but still less than the 6-7 kgs if the local vessels were loading. The price was generally $\mathrm{Rp} 25,000$ per large bucket ( USD 0.50 per kilo). Over $30 \%$ of the bait used in the trip was obtained from bagans and was usually of good quality if correctly and carefully loaded.

\section{TAG RECOVERIES}

Associated with the tagging cruise, wide publicity was undertaken, with posters publicizing the PTTP prepared in Bahasa Indonesia and widely distributed; TRO (tag recovery officers) were appointed in key ports and landings sites to publicize the project, collect tags with associated recapture information and pay the reward of Rp 100,000 (USD 10) for return of each tag. Although coverage may have been not complete throughout eastern Indonesia but the TRO was already well trained regarding the tags recoveries process.

\section{PRELIMINARY RESULT OF RECAPTURES}

Informationt from TRO (tag recoveries officer) in contributed countries and especially form Indonesia sites show that recovery number in late March 2011 was skipjack $3796(19.4 \%)$, yellowfin $786(14.9 \%)$, bigeye 70 (19.8\%). The total recaptures was 4652 $(18.4 \%)$ which was considered a moderately high return rate. Note that actual number of recaptures may be considerably higher, since there are known sources of non-reporting e.g. canneries and some landing points. Recovery rate by tag type compared to the 
releases was not significantly different $18.0 \%$ (1158) for $Z$ tags, 18.6\% (3494) for $P$ tags.

Recoveries percentage by size class shows slight variation but may not be significant. Recoveries for each size class was $18.7 \%$ for $30-34 \mathrm{~cm}$ size class $(1,273$ released $) ; 17.3 \%$ for $35-39 \mathrm{~cm}$ size class $(15,157) ; 20.3 \%$ for $40-44 \mathrm{~cm}$ size class $(6,670) ; 21.4 \%$ for $(1,414) ; 20.5 \%$ for $50-54 \mathrm{~cm}$ size class (547); and $14.6 \%$ for $55-59 \mathrm{~cm}$ size class (137). The highest recovery was found on $45-49 \mathrm{~cm}$ size class.

The movement of the tagged fish was described on Figures 11 to 13 this arrow plot of the movement was selected only for Indonesian area released tags recoveries derived from year 2011 SPC database. The movement pattern shows that most of the skipjack were recaptured again around the FADs where they are released, whilst yellowfin and big eye tuna have a longer and dispersed movement. The movement of the tagged fish could be grouped into two movements; outward movement and inward movement.

\section{OUTWARDS MOVEMENT (emigration)}

Recoveries from 2008 releases in Indonesia were made from a wide area of the western Pacific, with 439 (over $9 \%$ ) of releases to date. Most of these were from contiguous areas/EEZs eg PNG (133 recoveries), Palau (133), Philippines (64), and international waters/ high seas pocket (86), but also South China Sea (8), FSM (39), Malaysia (4), Nauru (1) and Vanuatu (1). Most of the international recoveries were skipjack (349), with 88 yellowfin and 8 bigeye.

\section{INWARDS MOVEMENT (immigration)}

Relatively fewer recoveries have been made in Indonesian waters from releases elsewhere in the WCPO by the project (approx. 225,000 releases, excluding the Indonesian releases), with only 317 to date eg PNG 131, Palau 135, FSM 28, and Solomons 16 , with one each from Philippines and Kiribati. Although these recoveries still require verification, it can possibly be inferred that nett emigration occurs, but with significant immigration of yellowfin relative to skipjack.

Most recaptures were recaptured in Indonesian waters but some over a wide range of the western and central Pacific. Following verification of tag recapture data, collaborative analyses involving SPC and RCFMC scientists will be undertaken, are expected to provide much valuable information on migration, exploitation rate and population dynamics of Indonesian tunas.

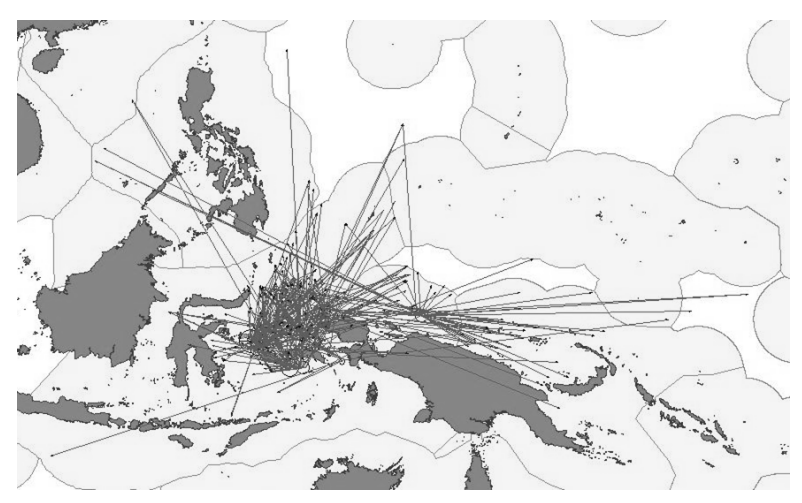

Figure 11. Movement pattern from yellowfin recoveries

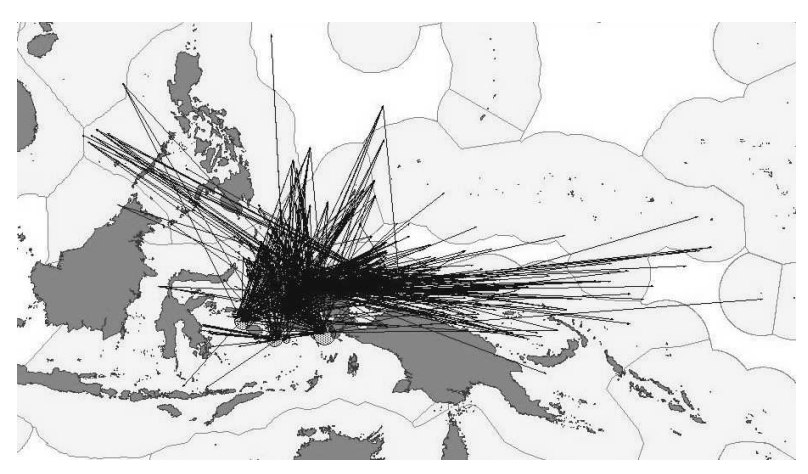

Figure 12. Movement pattern from skipjack recoveries

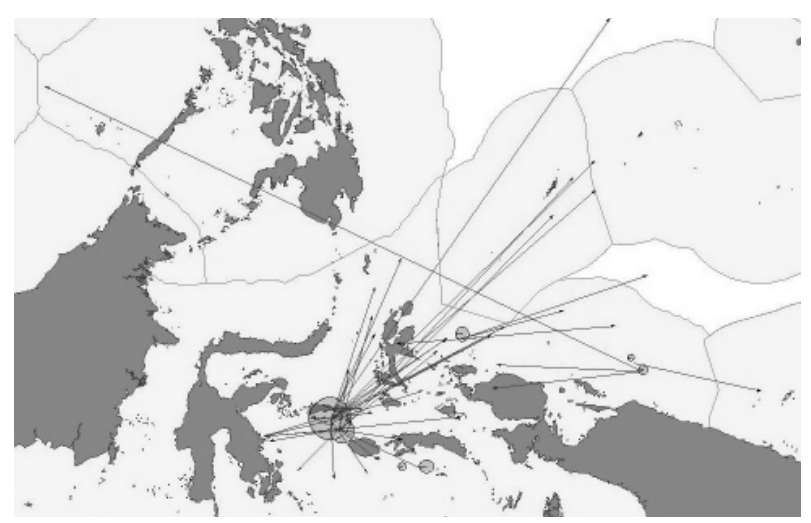

Figure 13. Movement pattern from bigeye recoveries

Tagging data from Indonesian waters will contribute during the analysis for regional Western and Central Pacific Ocean tuna assessment. The assessment will be comprised of movements, growth, mortality and longevity. The tagging data nevertheless provide important information for stock assessment. A subset of tuna tag returns provides useful information on growth rates. The most important contribution of the tagging data of tuna stock assessment is in the 
estimation of natural mortality. Natural mortality is estimated internally by the stock assessment model. Tagging data also have the potential to provide substantial information on exploitation rates of the tuna fishery. (Hampton \& Williams. 2005).

\section{CONCLUSIONS}

From the number of fish being released the 2008 tagging cruised can be concluded as a highly successful cruise and also good coverage cruise with a large number of fish tagged over a wide area of the Pacific, of the eastern Indonesian waters EEZ. Higher percentage of skipjack than other fish groups but still good proportion of yellowfin and bigeye. The average size of 2008 tuna tagging was mostly higher than previous tagging in 1991 except for skipjack, from the size variation aspect 2008 were lower than 1991 tagging. Availability of baitfish for tuna fishing was excellent all over the cruise area, which made wide coverage possible. Recoveries from 2008 tagging until March 2011 were considered as moderate.

\section{ACKNOWLEDGEMENT}

This cruise was part of Pacific Tuna Tagging Project (PTTP) Phase 22008 collaboration between SPC/ OFP and is part of the overall Pacific Tuna Tagging Project. Thanks to the cooperation of many people, especially Dr. John Hampton as project leader, Dr Tony Lewis as cruise leader for most of the tagging cruise, and Dr. Victor Nikijuluw as Director of RCCF (now change to RCFMC) during the cooperation.

\section{REFERENCES}

Gafa, B, T. Suhendrata, \& J. C. B. Uktolseja. 1987. Tagging on skipjack (Katsu-wonus pelamis) and yellowfin tuna (Thunnus albacares) around rumpon at Tomini Bay, North Celebes. Jurnal Penelitian Perikanan Laut. 43: 67-74.
Gafa, B \& K. Susanto. 1991. Some aspects of tagging on skipjack (Katsuwonus pelamis) and small yellowfin Tuna (Thunnus albacares) in Bacan island, North Mollucas and Luwuk, central Celebesweaters. Jurnal Penelitian Perikanan Laut. 63: 27-42.

Hampton J. \& P. Williams, 2005. A description of tagrecapture data for bigeye tuna (thunnus obesus) in the western and central pacific ocean. Col. Vol. Sci. Pap. ICCAT. 57 (2): 85-93.

Ishii, T. 1979. Attempt to estimate migration of fish population with survival parameters from tagging experiment data by the simulation method. Inves. Pesq. 43 (1): 301-317.

Itano, D., \& L. Joel Opnai. 1991. Regional Tuna Tagging Project Activity Report-Indonesia 1. South Pacific Commission, Tuna and Billfish Assessment Programme, RTTP Activity Report. 8: 32.

Jones R. 1977. Tagging: Theoretical methods and Practical Difficulties. In Fish Population Dynamics. J.A. Gulland (Editor). John Wiley \& Sons, Toronto, Canada.

Ricker W.E. 1975. Computation and interpretation of biological statistics of fish populations. Bull. Fish. Board Can. 191: 149-155.

http://www.spc.int/tagging/en/about-tagging accessed on 13 March 13, 2011. 


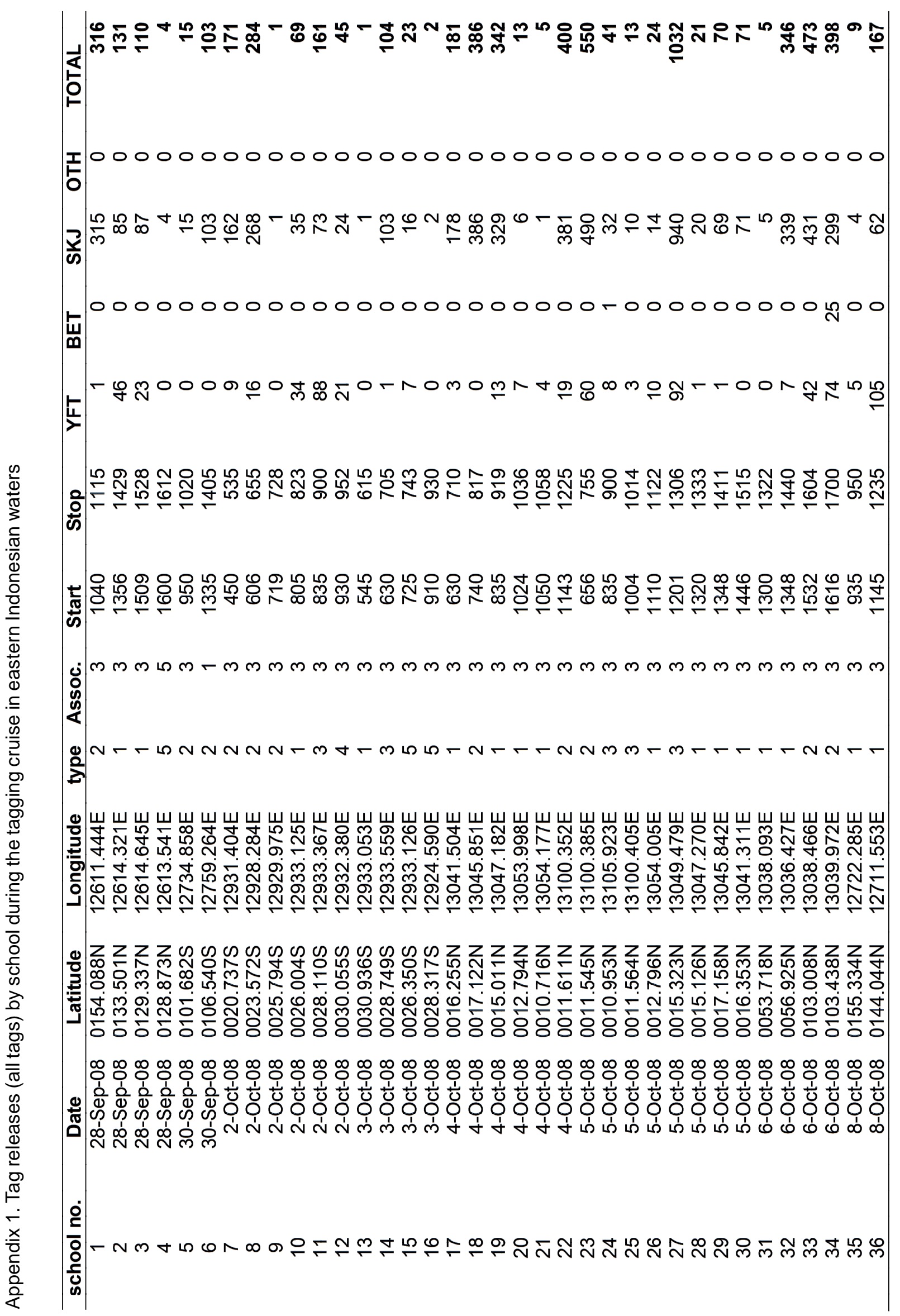




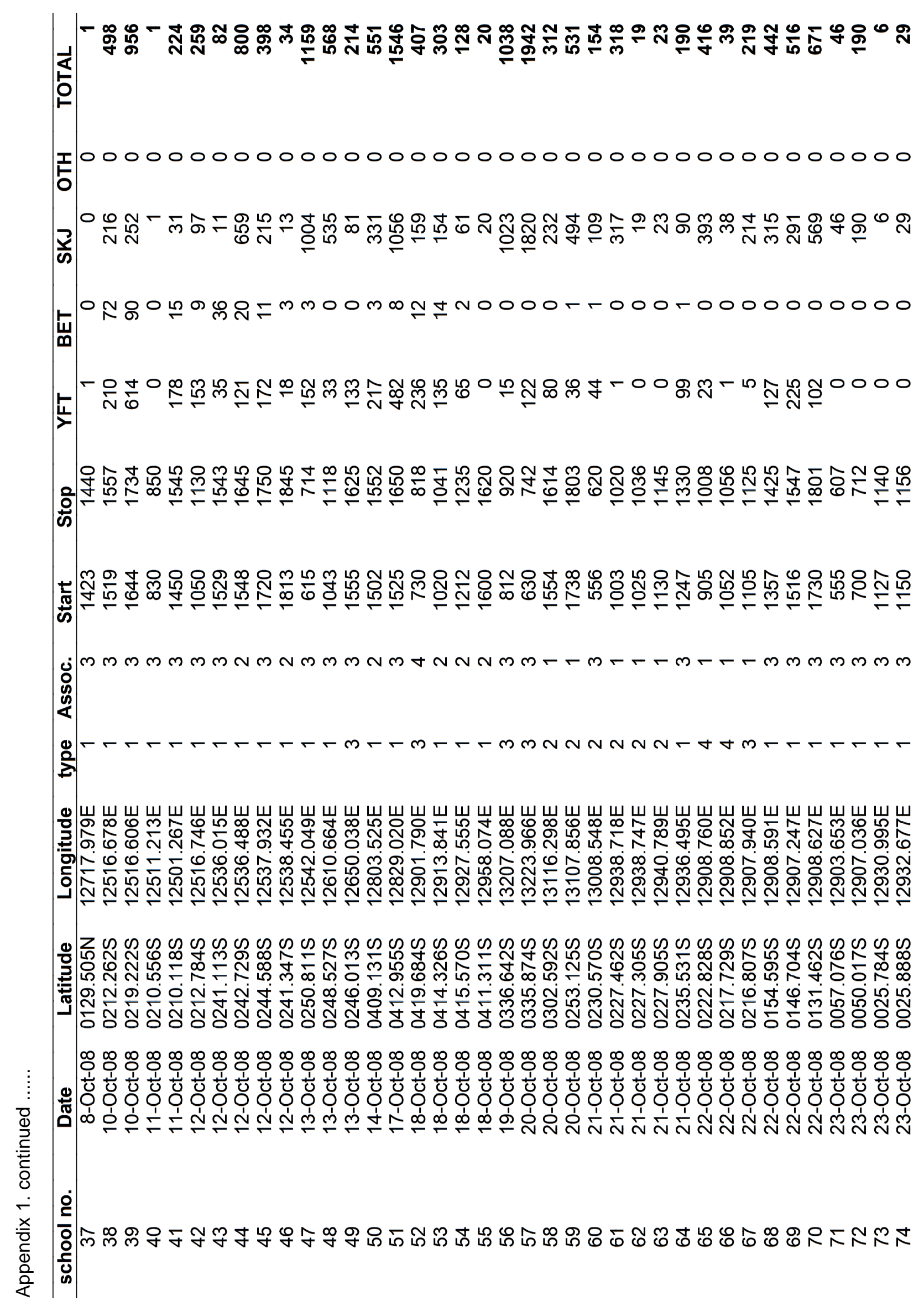




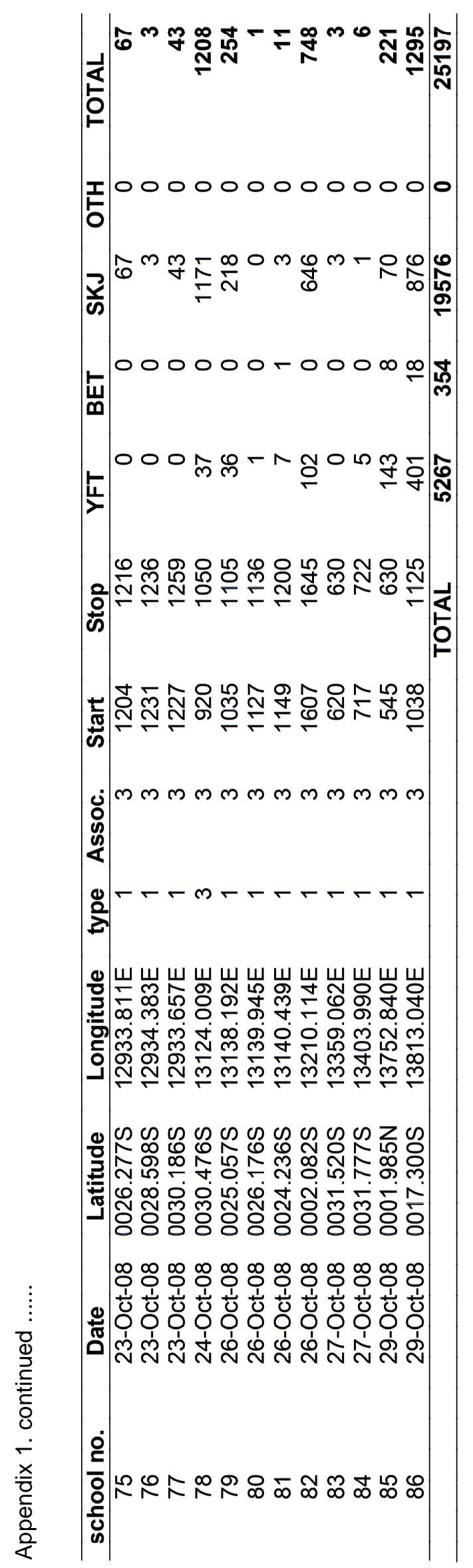

